\title{
Analysis of Factors Causing Delay in Unloading Imported Goods
}

\author{
Siti Sahara ${ }^{1 *}$ \\ ${ }^{1}$ Transportation, Faculty of Engineering State University of Jakarta, Indonesia \\ *Corresponding author. Email: sitisahara@unj.ac.id
}

\begin{abstract}
Currently the interest in imported goods is very high. Where imported goods have relatively affordable prices with quality in accordance with consumer needs. Therefore, the role of loading and unloading companies in handling imported goods has an important role because they are guided to have reliability regarding the delivery time of goods, efficient and cost-effective. This research was conducted to determine the factors causing the delay in loading and unloading activities. The data in this study consisted of primary data in the form of interviews and direct observations regarding the condition and situation of the object under study. While the primary data is in the form of documentation regarding the number of ship visits and the number of imported goods handled. The research method was carried out with a qualitative descriptive method. Based on the results of the analysis that the factors that affect the delay in delays in imported goods are uncontrollable factors with a percentage of $80 \%$ with aspects of open-close hatch cover and troubel quay equipment which greatly affect the delay in delays in imported goods with a percentage of $26 \%$ and $41 \%$ of the total uncontrollable factor.
\end{abstract}

Keywords: Delay, unloading, imported goods, controllable factor

\section{INTRODUCTION}

Social development is also human development that does not only rely on existing resources but the accumulation of resources for productive activities and increasing material prosperity. At a macro level, indicators of the efficiency of a country's economic development can be seen from assessing efficiency, total volume of national production per capita, sectoral structure of the national economy, production of basic products per capita, level and quality of life, and international trade [4]. International trade has an important role in the production process and consumption decisions [1]. Currently the interest in imported goods is very high. Where imported goods have relatively affordable prices with quality in accordance with consumer needs [8].

Indonesia is a country rich in natural resources spread throughout its territory with a population of $270,203,917$ people. But even so, Indonesia in meeting the needs of the community cannot be separated from import activities. Based on data from the Central
Statistics Agency, the number of imported goods entering Indonesia from January 2020 to April 2021 is as follows:

Intermodal and multimodal transportation play a central role in the global market competition system in the 21st century [6]. Especially loading and unloading companies that take care of the process of shipping goods from the global market. Loading and unloading companies are required to have reliability regarding the delivery time of goods [10]. In addition, loading and unloading companies are expected to provide efficient and cost-effective services [2]. One of the companies engaged in loading and unloading of goods is PT. Tough Ocean Jaya. PT. Tangguh Samudera Jaya (TSJ) is engaged in loading and unloading services (PBM) for international container ships and continues to handle breakbulk vessels and domestic containers at Terminals 1 and 2 of Tanjung Priok Port. regulate the separation of loading and unloading activities from shipping companies. 
Table 1. Number of Imported Goods Entering Indonesia.

\begin{tabular}{|c|c|c|c|}
\hline No & Month & Import Value (US\$) & Import Weight (Kg) \\
\hline 1 & January 2020 & $14,268,720,284.00$ & $12,143,552,871.00$ \\
\hline 2 & February 2020 & $11,548,100,132.00$ & 13.059 .584 .031 .00 \\
\hline 3 & March 2020 & $13,352.176,374.00$ & $14,432.183 .255 .00$ \\
\hline 4 & April 2020 & $12,535,233,221.00$ & $15,051,046,827.00$ \\
\hline 5 & May 2020 & $8,438,627,383.00$ & $10,084,426,066.00$ \\
\hline 6 & June 2020 & $10,760,317,981.00$ & $11,505,323,617.00$ \\
\hline 7 & July 2020 & $10,464,299,676.00$ & $11,323,464,029.00$ \\
\hline 8 & August 2020 & $10,742,407,847.00$ & $11,839,690,849.00$ \\
\hline 9 & September 2020 & $11,570,104,770.00$ & $12,883,228,618.00$ \\
\hline 10 & October 2020 & $10,786.016,684.00$ & $12,091,546,513,00$ \\
\hline 11 & November 2020 & $12,664,414,194.00$ & $12,137,149,554.00$ \\
\hline 12 & December 2020 & $14,438,376,084.00$ & $15,330,669,376.00$ \\
\hline 13 & January 2021 & $13,329,901,020.00$ & $13,078,332,805.00$ \\
\hline 14 & February 2021 & $13,264,974,634.00$ & $12,378,562,385,00$ \\
\hline 14 & March 2021 & $16,787,511,490.00$ & $17,281,282,068.00$ \\
\hline 16 & April 2021 & $16,204,338,764.00$ & $15,359,269,116.00$ \\
\hline
\end{tabular}

PT. Tangguh Samudera Jaya has loading and unloading equipment consisting of 2 units of Container Crane (CC), 2 units of Mobile Harbor Cranes (HMC), 10 units of Rubber Tyred Gantry Crane (RTGC), and 4 units of Reach Stacker (RS) with the number of containers served in 2020 are as follows:

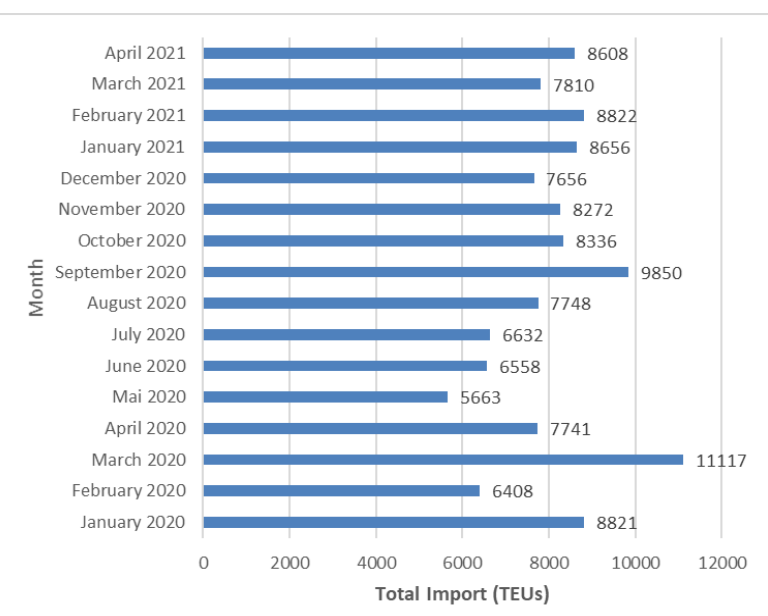

Figure 1 Total Import Cargo Served by PT. Tangguh Samudera Jaya.
The high number of imported cargo served makes PT. Tangguh Samudera Jaya always ensures the quality of its services. But in reality. there are often delays in the process of unloading imported goods. The delay in this unloading activity will be detrimental to all parties. For the expedition, because the time the ship is leaning in the port is getting longer, it costs more. As a result, the expedition or distributor of goods will increase the selling price to cover losses from the length of time the ship has docked. In addition, this will also have an impact on decreasing interest in expeditions using the loading and unloading services of PT. Tough Ocean Jaya. Many factors cause delays in the process of unloading imported goods. For that.

\subsection{Literature Review}

Along with increasingly complex and diverse human needs, the activity of moving goods is getting higher [7]. Especially sea transportation activities are widely used in international trade. Services in sea transportation activities cannot be separated from loading and unloading activities that require the role of loading and unloading companies. Loading and unloading activities start from ships anchored and moored at the dock. Then one by one the containers are transferred from the ship to the truck to be taken to the stacking yard or to the goods owner [3]. Loading and 
unloading activities have also been regulated as stated in Article 2 of the Regulation of the Minister of Transportation Number. 60 of 2014 which states that the business activities of loading and unloading goods from and to ships at the port whose mechanisms include stevedoring, cargodoring, and receiving/delivery and carried out by a business entity that has a business license and was specifically established for loading and unloading [5]. Further, the Decree of the Minister of Transportation No. KM.88/AL.305/phb-85 concerning companies loading and unloading goods from and to ships confirms that the scope of loading and unloading activities at the port includes:

1. Stevedoring, which is the work of unloading goods from the ship to the dock/truck or loading goods from the dock/truck into the ship until it is arranged into the ship's hold using a ship crane or other loading and unloading equipment.

2. Cargodoring, which is the work of releasing goods from ropes/nets at the dock and transporting them from the dock to the warehouse/ stockpiling yard and then arranged in the warehouse/ stacking yard/ vice versa.

3. Receiving/delivery, the work of moving goods from the stacking place in the warehouse/stack yard and handing them over until they are arranged on a vehicle at the warehouse/field door/ vice versa.

In practice, there are several factors that affect the length of the loading and unloading process, including truck delays, loading and unloading labor, loading delays, and weather conditions [11]. Meanwhile, according to Noorul Shaiful Fitri Abdul Rahman, the geographical location of the port, the type of port equipment, and the level of port infrastructure can affect the length of time for loading and unloading activities [12]. Nasser Saeidi explained that the main factors for the delay in loading and unloading activities were the lack of or not functioning properly at the dock equipment, costs, administration, improper storage of goods in the stacking yard, unpreparedness of loading and unloading workers (TKBM), sea tides, shortage of loading and unloading equipment on board, official or public holidays, and bad weather [13]. So that the researchers conclude that the factors that cause delays in loading and unloading activities can be classified into two factors, namely controllable factors and uncontrollable factors. Where controllable factors are factors that can cause delays in controlled import activities when this occurs. Meanwhile, uncontrollable factors are factors that cannot be controlled by the operational party or the company.

\section{METHODS}

The purpose of this study was to determine the factors causing delays in the activities of loading and unloading imported goods, especially at PT. Tough Ocean Jaya. This research was conducted at PT. Tangguh Samudera Jaya, Complex. Yos Sudarso Megah, J1. Yos Sudarso No.1, RT.16/.6, Kebun Bawang, Tanjung Priok, North Jakarta City 14320. Data collection was carried out from January to March 2021. The data in this study consisted of primary data in the form of interviews and direct observations about the condition and the situation of the object under study. While the primary data in the form of documentation regarding the number of ship visits and the number of imported goods handled by PT. Tangguh Samudera Jaya uses observation sheets, documentation, and interviews with related parties. The data that has been obtained is processed in the form of tables, graphs and images. The research method is carried out with a qualitative descriptive method which is intended to obtain results that describe in detail the factors causing delays in the loading and unloading of imported goods at PT. Tough Ocean Jaya.

This research begins by formulating the problems that occur in the activities of loading and unloading imported goods by providing limitations that are adjusted to the objectives and benefits to be achieved in this study. Subsequently, secondary data was collected, namely data related to the number of cargo imports, the number of ships arriving, the number of loading and unloading equipment owned by the company, and the number of workers (TKBM). Based on the existing secondary data, the researcher designed a research instrument to collect primary data in the form of an interview instrument aimed at the parties involved in the loading and unloading of imported goods as well as an observation instrument to determine the extent to which these factors can cause delays in the loading and unloading of imported goods.

After all the necessary data has been collected, the researcher analyzes the data and determines the dominant factors that cause delays in the activities of imported goods. 


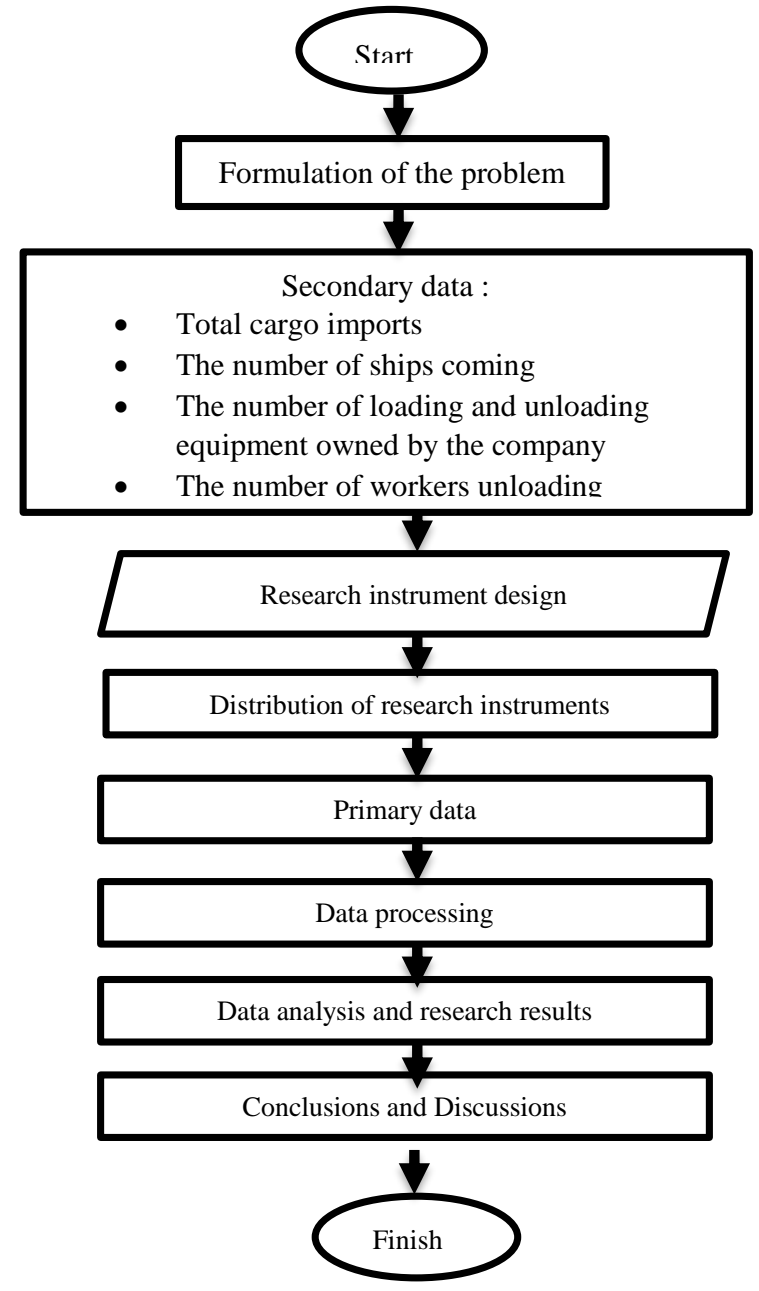

Figure 2 Research Design

After all the data has been analyzed and the results obtained, a conclusion can be made from the entire series of tests that have been carried out and suggestions that can be used to improve existing conditions so as to reduce the occurrence of delays in the implementation of loading and unloading of imported goods.

\section{RESULT AND DISCUSSION}

Planning is the starting point of an activity of loading and unloading imported goods. The success of an activity comes from good planning, resulting in a suitable target even more than previously planned. The process of planning for the unloading of imported goods begins with determining the equipment to be used based on the size of the ship, the position of the container to be unloaded, the number of goods, and

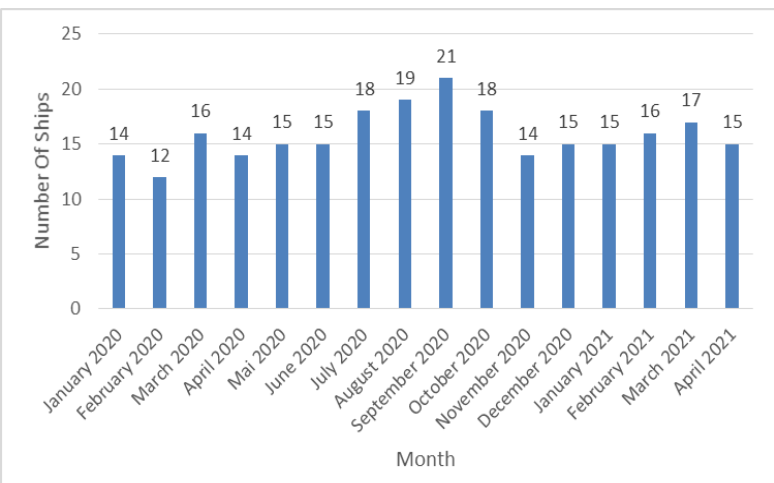

Figure 3 Number of Ship Visits at PT. Tangguh Samudera Jaya

customer requests for additional equipment to be used in order to speed up the loading and unloading of imported goods. In carrying out the activities of loading and unloading imported goods, PT. Tangguh Samudera Jaya provides sufficient human resources consisting of 88 loading and unloading workers (TKBM) which are divided into 4 teams. The data on ship visits at PT. Tangguh Samudera Jaya are as follows:

Based on the data obtained, fluctuations occurred during the period January 2020 to April 2021. The highest ship visits occurred in September 2020 with a total of 21 ships, and the lowest ship visits in February 2020 with 12 ships. While the high number of imported goods handled by PT. Tangguh Samudra Jaya occurred in the March 2020 period with 11,117 TEUs of imported goods and the lowest period occurred in May 2020 with 5,663 TEUs of imported goods. In this study, researchers classify the factors causing delays in the activities of imported goods into two factors, namely controllable factors and uncontrollable factors.

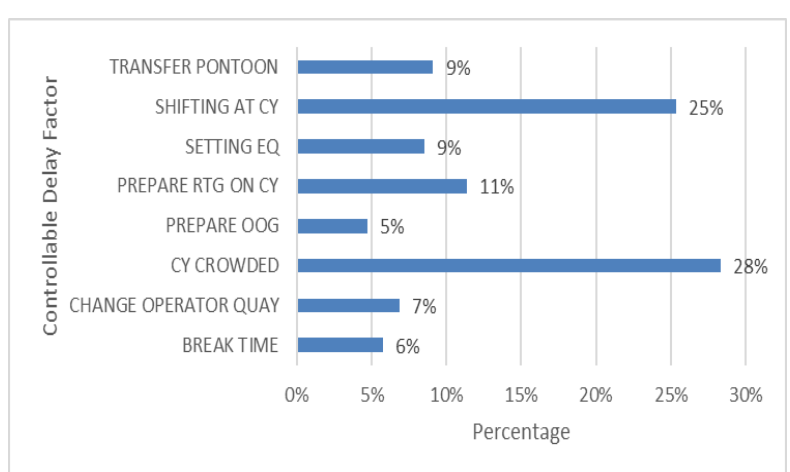

Figure 4 Controllable Delay Factor Import Unloading Activities 
In simple terms, controllable factors are factors that can cause delays in controlled import activities when this occurs. Controllable factors consist of break time, change operator QC, CY crowded, prepare OOG, prepare RTG on CY, equipment setting, shifting at CY, and pontoon transfer.

Break Time is one of the factors causing loading and unloading delays with a percentage of $6 \%$ of the total Idle Time Controllable factor. This is because many workers overestimate their rest time, causing delays in the process of loading and unloading imported goods. Quay Crane Operator Change occurs when the Quay Container Crane operator shift is changed. This factor causes delays in unloading activities by $7 \%$. Container Yard Crowded was caused by Container Yard being busy so that many containers interfered with the mobility of other loading and unloading equipment, causing delays in activities by 28\%. Prepare loading Out Of Gauge Container (OOG) is an activity in preparing tools and other facilities used in loading and unloading activities. Prepare to load Out Of Gauge Container (OOG) is one of the factors causing delays with a percentage of $5 \%$, this is because there are several containers that require special equipment and treatment. Prepare RTG on CY is an activity to prepare a Rubber Tyred Gantry Crane (RTG) at the Container Yard in the implementation of cargodoring. Prepare RTG on CY is done carefully because before the RTG operates, the RTG must be checked for the condition of the tires, gasoline, as well as the condition of the equipment causing a delay of $11 \%$. Setting Equipment is an activity in preparing Quay Crane, Rubber Tyred Gantry Crane, Reachstacker, and trucks that will be used during the unloading of imported goods so that there are no obstacles so that the tool preparation process takes time which is often not in accordance with the predetermined schedule. The equipment setting factor causes delays in the loading and unloading of imported goods by $9 \%$. Shifting at CY is an activity to move containers based on the container bay plan. Shifting at CY causes delays in loading and unloading of imported goods by $25 \%$ because often the container is in a lower position, so to pick it up you have to move the container above. The last factor of delay in unloading Controllable activities is pontoon transfer with a percentage of $9 \%$. Pontoon transfer is an activity to move the hatch cover of the ship so that the containers under the deck can be moved.

Uncontrollable factors are factors that cannot be controlled by the operational party of PT. Tough Ocean Jaya. Controllable factors consist of approval custom clearance $(\mathrm{C} / \mathrm{O})$, bad weather, clash at $\mathrm{CY}$, clash ship equipment, cargo handling, move to other vessel, open-close hatch cover, shifting on vessel, ship idle, troubel CY equipment, troubel non-equipment, troubel quay equipment, update bay plan, and control tower.

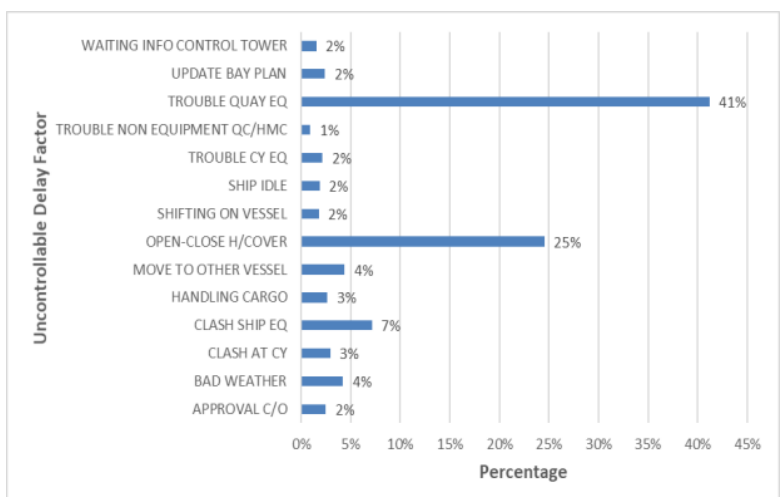

Figure 5 Uncontrollable Delay Factor Import Unloading Activities

Approval custom clearance $(\mathrm{C} / \mathrm{O})$ is the waiting time for customs approval for the implementation of loading and unloading of imported goods with a percentage of $2 \%$. This happens because customs clearance has not been completed by the owner of the goods when the ship arrives. Bad Weather is a natural weather condition that is currently bad so that it interferes with the smooth operation of loading and unloading of imported goods, especially during the rainy season period from December to March with a percentage of $4 \%$. Clash at CY is an event that causes delays in loading and unloading imported goods due to a collision between the Rubber Tyred Gantry Crane (RTG) in the Container Yard with a percentage of $3 \%$.

Clash Ship Equipment is an event that causes delays in loading and unloading imported goods due to a collision between Crane Container on the dock or on board with the Harbor Mobile Crane (HMC) at the dock with a percentage of $7 \%$. Handling Cargo is an activity of loading and unloading imported goods that needs to be carried out carefully because it is related to special containers such as Container Dangerous Goods (DG) and Container Over Dimension (OD) so that sometimes the unloading process does not match the specified time. The Cargo Handling factor causes delays with a percentage of $3 \%$. Move to Other Vessel is one of the delay factors with a percentage of $4 \%$ caused by the process of moving equipment from ship "A" to ship "B". This happens because sometimes during the process of unloading imported goods,

Open-Close Hatch Cover is the process of opening and closing the hatch on a ship. This process 
is often the cause of delays with a percentage of $25 \%$ because the number of hatches on the ship consists of 8 to 12 hatches so that the time required is often not according to schedule. Shifting on Vessel is an activity to move containers based on the container bay plan on the ship. Shifting on Vessel causes delays in loading and unloading of imported goods by $2 \%$ because the container is often in a lower position, so to retrieve it, you have to move the container above it. Ship Idle is the waiting time for ships before the process of unloading activities that occurs because the dock is full which makes the delay in the unloading process by $2 \%$. Trouble CY Equipment occurred because the Rubber Tyred Gantry (RTG) and Reach Stacker (RS) at the container yard had trouble (damage) resulting in a $2 \%$ delay in the unloading process. Trouble Non Equipment QC/HMC is damage to non-equipment Quay Container Crane (QC) or Harbor Mobile Crane (HMC) which is damaged, resulting in a $1 \%$ delay in the unloading process.

Trouble QC Equipment is damage to dock equipment such as Quay Container Crane (QC) or Harbor Mobile Crane (HMC) which causes delays in the unloading process by $41 \%$. This happens because the Quay Container Crane (QC) or Harbor Mobile Crane (HMC) is the main tool in the process of unloading imported goods at the dock. Bay Plan Update is the process of changing the bay plan that has been planned and then adjusted to the conditions in the field so as to make the unloading process delay by $2 \%$. The last aspect of the uncontrollable factor is the waiting info control tower. Waiting info control tower is the process of waiting for further information regarding the implementation of loading and unloading of imported goods at terminal 3 ports.

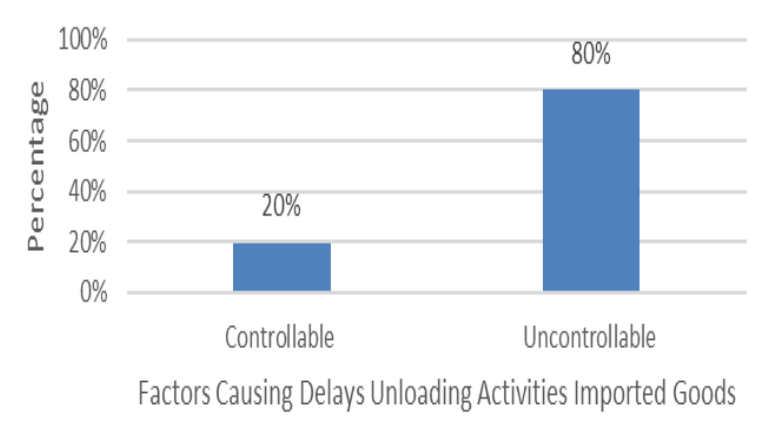

Figure 6. Factors Causing Delays Unloading activities Imported Goods
So overall the factors that affect the delay in loading and unloading imported goods are uncontrollable factors with a percentage of $80 \%$ consisting of aspects of approval custom clearance $(\mathrm{C} / \mathrm{O})$, bad weather, clash at $\mathrm{CY}$, clash ship equipment, cargo handling, move to other vessel, open-close hatch cover, shifting on vessel, ship idle, troubel CY equipment, trouble non-equipment, trouble quay equipment, update bay plan, and control tower.

While controllable factors affect the delay in loading and unloading imported goods with a percentage of $20 \%$ consisting of aspects of break time, change operator QC, CY crowded, prepare OOG, prepare RTG on CY, equipment setting, shifting at CY, and transfer pontoon.

\section{CONCLUSION}

Based on the results of the analysis, it is concluded that the factors that affect the delay in loading and unloading imported goods are uncontrollable factors with a percentage of $80 \%$. the percentages are $25 \%$ and $41 \%$, respectively, of the total uncontrollable factors. While the controllable factor affects the delay in loading and unloading imported goods with a percentage of $20 \%$. Aspects that greatly affect the delay in loading and unloading of imported goods on controllable factors are CY crowded and shifting at CY with a percentage of $28 \%$ and $26 \%$, respectively, of the total controllable factors.

Based on the conclusions obtained from the analysis of the factors causing the delay in the loading and unloading of imported goods, it was found that the condition of the equipment was the biggest factor causing the delay in the loading and unloading of imported goods. For this reason, loading and unloading companies should pay attention to every condition of the equipment, both in terms of maintenance, repair, and the number of tools, especially Quay Container Crane (QC), Harbor Mobile Crane (HMC), and Rubber Tyred Gantry Crane (RTG) which are the main tools in unloading activities. So that it can fulfill the service of loading and unloading imported goods effectively and efficiently.

\section{REFERENCES}

[1] Ahmed, R. R., Ghauri, S. P., Vveinhardt, J., \& Streimikiene, D. (2018). An empirical analysis of export, import, and inflation: A case of Pakistan. Romanian Journal of Economic Forecasting, 21(3), 117-130. 
[2] Cullinane, K. P. B., \& Wang, T. (2014). The efficiency of European container ports: A cross-sectional data envelopment analysis. International Journal of Logistics Research and Applications: A Leading Journal of Supply Chain Management, June 2014, 37-41. https://doi.org/10.1080/13675560500322417

[3] Khafid, N., \& Syairudin, B. (2019). A concept to Reduce Idle Time on Stevedoring Activities in a Container Terminal. IPTEK Journal of Proceedings Series, $0(1), \quad 43$. https://doi.org/10.12962/j23546026.y2019i1.510 5

[4] Malyarets, L.M., Koibichuk, V.V., et al. (2021). Diagnostics of Efficiency of an Enterprise's Export-import Activity. Montenegrin Journal of Economics, 17(1), 71-83. https://doi.org/10.14254/1800-5845/2021.171.5 .

[5] Regulation of the Minister of Transportation of the Republic of Indonesia Number. 60 of 2014.

[6] Rondinelli, D., \& Berry, M. (2000). Multimodal Managing Interactions in a and the Environment: Transportation, Logistics, Global Economy. European Management Journal, 18(4), 398-410. https://doi.org/https://doi.org/10.1016/S02632373(00)00029-3

[7] Salvatore, D. (2007). International Economics. Prentice-Hall.

[8] Selivanova, M. V., Strizhkova, L. A., \& Tishina, L. I. (2019). Imported Goods' Demand Functions by the Main Areas of Use. 47(Iscfec 2018), 713716. https://doi.org/10.2991/iscfec-18.2019.174

[9] Stahlbock, R., \& Voß, S. (2008). Operations research at container terminals : A literature update a literature update. Springer-Verlag, 30(April), 1-52. https://doi.org/10.1007/s00291-007-01009

[10] Tongzon, J., \& Heng, W. (2005). Port privatization, efficiency and competitiveness : Some empirical evidence from container ports (terminals) I. 39, 405-424. https://doi.org/10.1016/j.tra.2005.02.001

[11] Rum Raekhan, M., Djakfar, L., \& Pujiraharjo, A. (2017). Evaluasi Kinerja Bongkar Muat di Pelabuhan Umum Gresik. Jurnal Transportasi, 17(2), 133-144.

[12] Rahman, N. S. F. A., Othman, M. K., Sanusi, I. A., Arof, A. M., \& Ismail, A. (2019). Evaluation of Delay Factors on Dry Bulk Cargo Operation in Malaysia: A Case Study of Kemaman Port. Asian Journal of Shipping and Logistics, 35(3), 127137. https://doi.org/10.1016/j.ajsl.2019.09.001
[13] Saeidi, N., Jafari, H., Khosheghbal, B., \& Alialaei, M. (2013). Managing the Causes of Delay in General Cargo Handling Operation. Journal of Basic and Applied Scinetific Research, 3(4), 419-424 